\title{
APPLICATION OF HEC-RAS MODEL FOR ESTIMATING CHANGES IN WATERCOURSE GEOMETRY DURING FLOODS
}

\author{
JOANNA MARKOWSKA \\ Department of Environmental Engineering, \\ Faculty of Environmental Engineering and Geodesy, \\ Wrocław University of Life Sciences, e-mail: joanna.markowska@up.wroc.pl
}

JACEK MARKowsKi, ANDRZEJ DRABIŃSKI

Department of Landscape Architecture, Faculty of Environmental Engineering and Geodesy, Wrocław University of Life Sciences, e-mail: jacek.markowski@up.wroc.pl, andrzej.drabinski@up.wroc.pl

\begin{abstract}
The article describes the progress of a hypothetical flood in a watercourse reach, including potential changes in the channel geometry. The quasi-hydrodynamic model employed takes into account changes in the temperature of the medium over time, the complex structure of the watercourse channel, almost any recharge pattern and any engineering structures in the channel. As a result, it is possible to estimate probable changes in the geometry of precisely reproduced reaches of existing watercourse channels during significant floods and include them, e.g., in real-time operational models.
\end{abstract}

\section{INTRODUCTION}

The problems of sediment transport in mathematical modelling have been studied for many years. Literature mentions a group of systematically developed models from the families: HEC-RAS, GSTARS, STAND and Fluvial-12 (Zenga and Beckb [7], Yang [6], Simon et al. [5]), which simulate sediment transport in an open channel with changeable bed. These tools are used to estimate changes in channel geometry during floods, useful in river training design, to describe the silting-up of river channels and reservoirs, contaminant transport, etc. They vary in the proposed approach to sediment transport modelling (the choice of numerical solution, phenomenon description by means of equations, the conditions of the phenomenon progress, etc.). A detailed comparison of HEC-RAS and STAND models was presented by Zenga and Beckb [7], who pointed to the most important differences including the fact that HEC-RAS is a quasi-hydrodynamic model while STAND - a fully hydrodynamic one and that STAND is based on a numerical solution of advection and dispersion equation, which produces an instantaneous value of sediment transport.

According to the authors, the simplified approach used in HEC-RAS model could perfectly work in a real-time operational model used for estimating watercourse channel geometry changes. 


\section{COMPUTER EXPERIMENT DESCRIPTION: TOOL, MATERIAL AND METHODS}

A computer experiment consisting in modelling water flow in an open channel and allowing for sediment transport phenomenon was conducted by means of HEC-RAS model.

HEC-RAS is a widely tested model developed by the US Corps of Engineers Hydraulic Engineering Centre. It is used as a tool for reproducing steady and unsteady flows in almost any hydraulically possible cases such as:

- Simple and complex river engineering works in channels: levees, weirs and barrages, high and low bridges, culverts, flow-through reservoirs, lateral reservoirs, pumping stations, etc.,

- Changing shape of the river valley and the main channel described by freely spaced cross-sections (interpolation techniques),

- Proportionally variable flow path lengths on floodplains and in the main channel, allowing for sediment transport and contaminant spread.

The application of this software amounts to feeding groups of input data including topographic, hydrologic and hydraulic data such as bed structure (type of material, grain size), data concerning contamination, etc. Simulation calculations performed in HEC-RAS enable analysing many scenarios, which could provide the basis for developing alternative concepts of increasing flood prevention in river valleys.

The authors' goal was to present a hypothetical flood in a watercourse reach, with potential changes in channel geometry, and to present the possibilities offered by HECRAS software. With this aim, the following elements of the experiment were adopted:

- Initial channel geometry,

- River engineering works in the channel,

- Channel bed structure,

- Discharge hydrographs,

- Water temperature.

The above elements determined the choice of computational methods available in HEC-RAS package.

The first step in the general operation algorithm was defining hydraulic flow conditions in the watercourse; then it was possible to start sediment transport calculations.

\subsection{INITIAL GEOMETRY OF THE CHANNEL}

Modelling was performed on a reach of a $10-\mathrm{km}$ long theoretical watercourse. It was assumed to be part of the middle course with mean bed slope $i=0.005$ and artificial trapezoid-shaped channel. The initial 3-km long reach with cross-sectional dimensions like those shown in Fig. 1 does not have any engineering works. 
Application of HEC-RAS model for estimating changes...

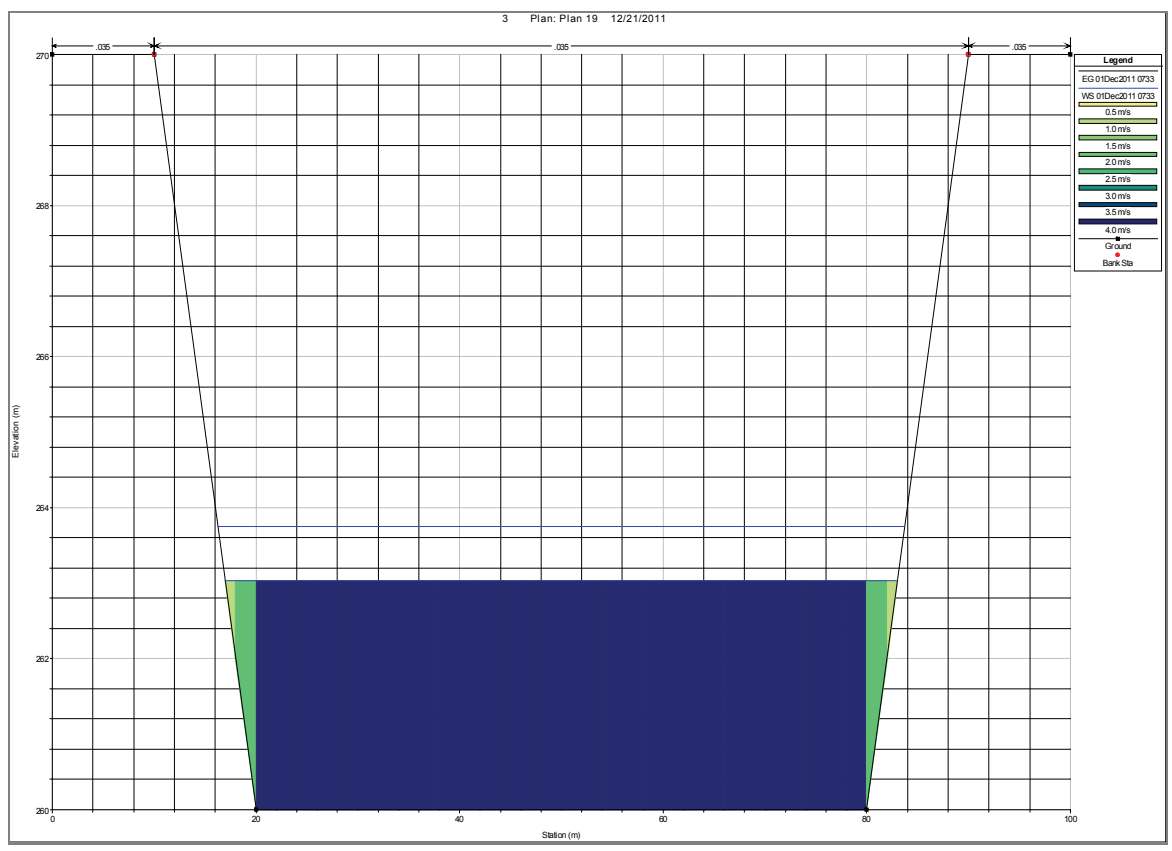

Fig. 1. An example of basic channel cross-section

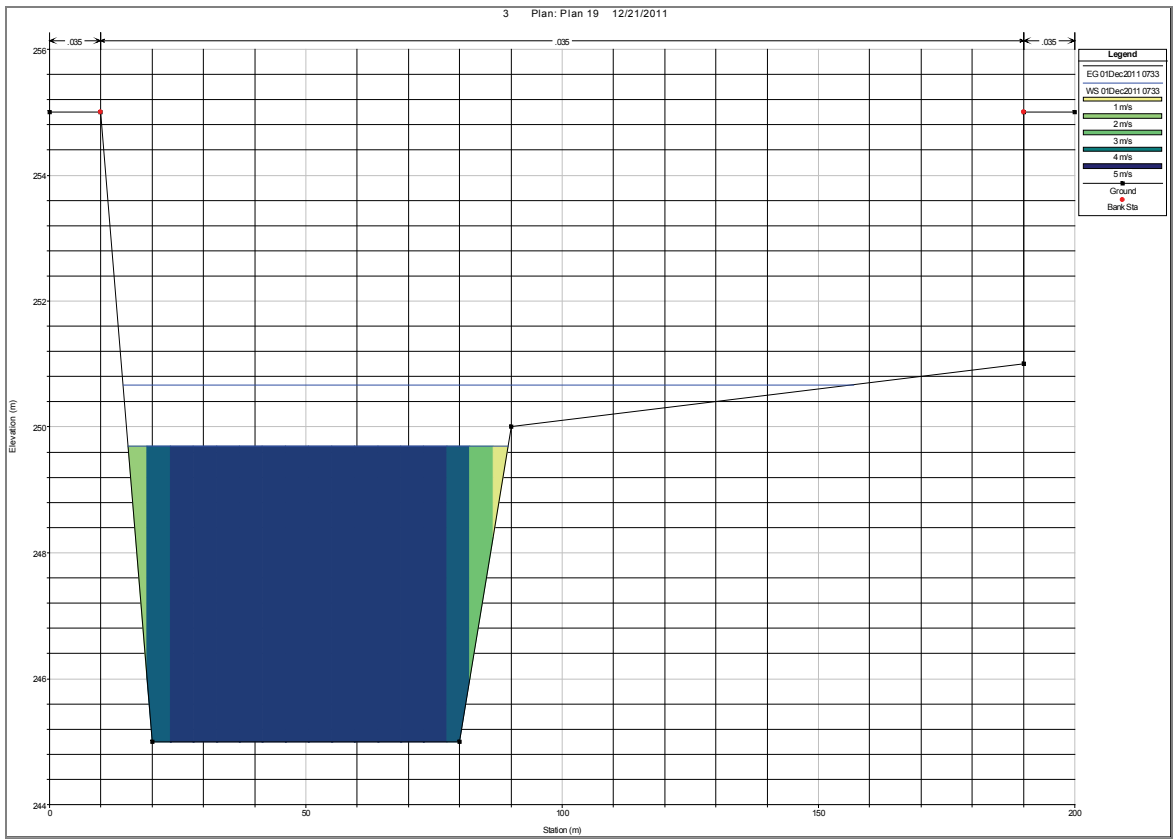

Fig. 2. Cross-section of the watercourse channel between $7+00$ and $5+00 \mathrm{~km}$ 
From $7+00$ to $5+00 \mathrm{~km}$, the channel has a floodplain like in the diagram of Fig. 2. At $4+900 \mathrm{~km}$ there is a local gradual narrowing of the channel by c. $50 \%$ of the crosssectional flow area compared to the cross-sections upstream of it. Along the reach between the $4+900 \mathrm{~km}$ cross-section and $4+800 \mathrm{~km}$, the channel widens proportionally to the initial dimensions, as shown in Fig. 1, and remains like this until $0+00 \mathrm{~km}$. The linear flow resistance coefficient $n=0.035$ was adopted over the whole modelled reach.

\subsection{RIVER ENGINEERING WORKS IN THE CHANNEL}

At $0+500 \mathrm{~km}$ there is a bridge, whose diagram is shown in Fig. 3, and at $1+005 \mathrm{~km}$ there is a permanent weir, shown in the diagram of Fig. 4. Along the reach between $0+00$ and $1+500 \mathrm{~km}$, there are cross-sections spaced at $1 \mathrm{~m}$ intervals, between $1+500$ and $4+800 \mathrm{~km}-$ at $100 \mathrm{~m}$ intervals, between $4+800$ and $7+00 \mathrm{~km}-$ at $10 \mathrm{~m}$ intervals, and between $7+00$ and $10+00 \mathrm{~km}-$ at $100 \mathrm{~m}$ intervals.

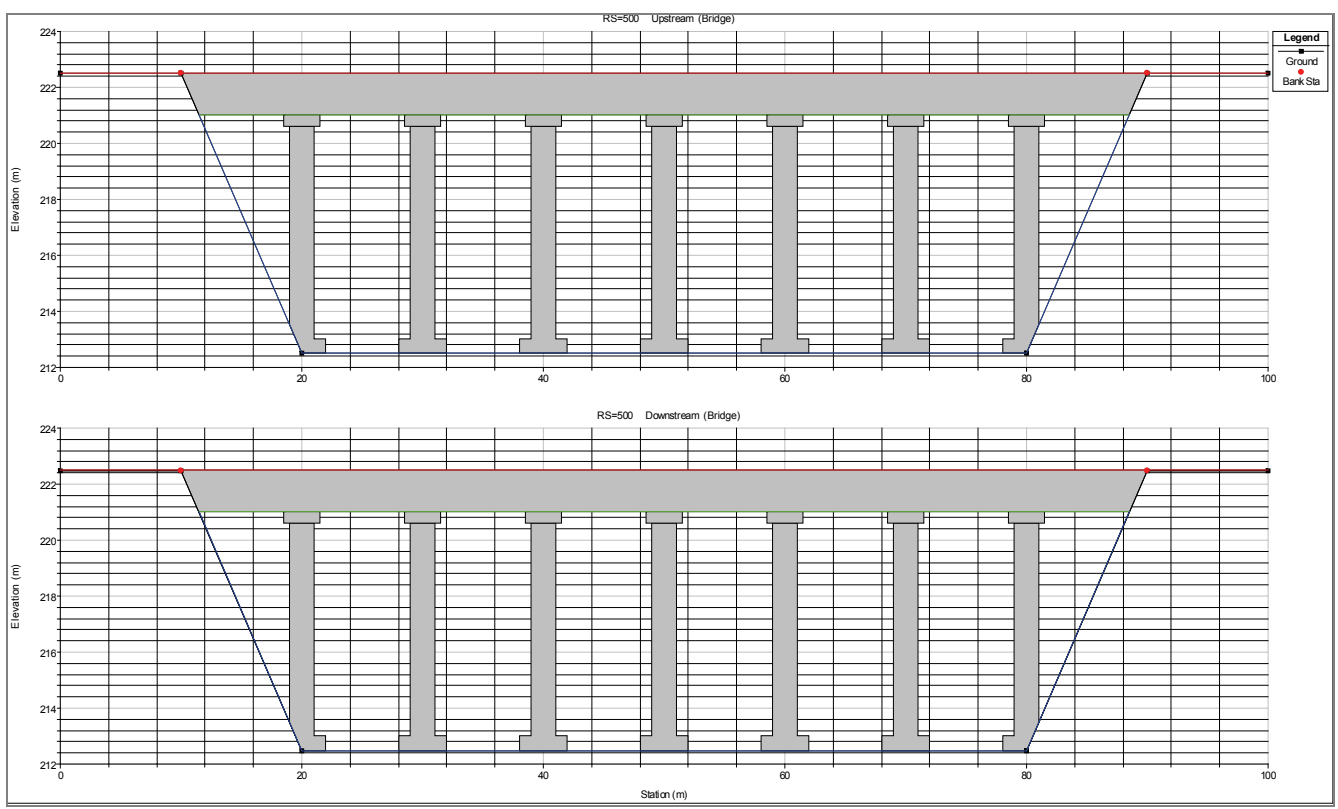

Fig. 3. Diagram of the bridge at $0+500 \mathrm{~km}$ 


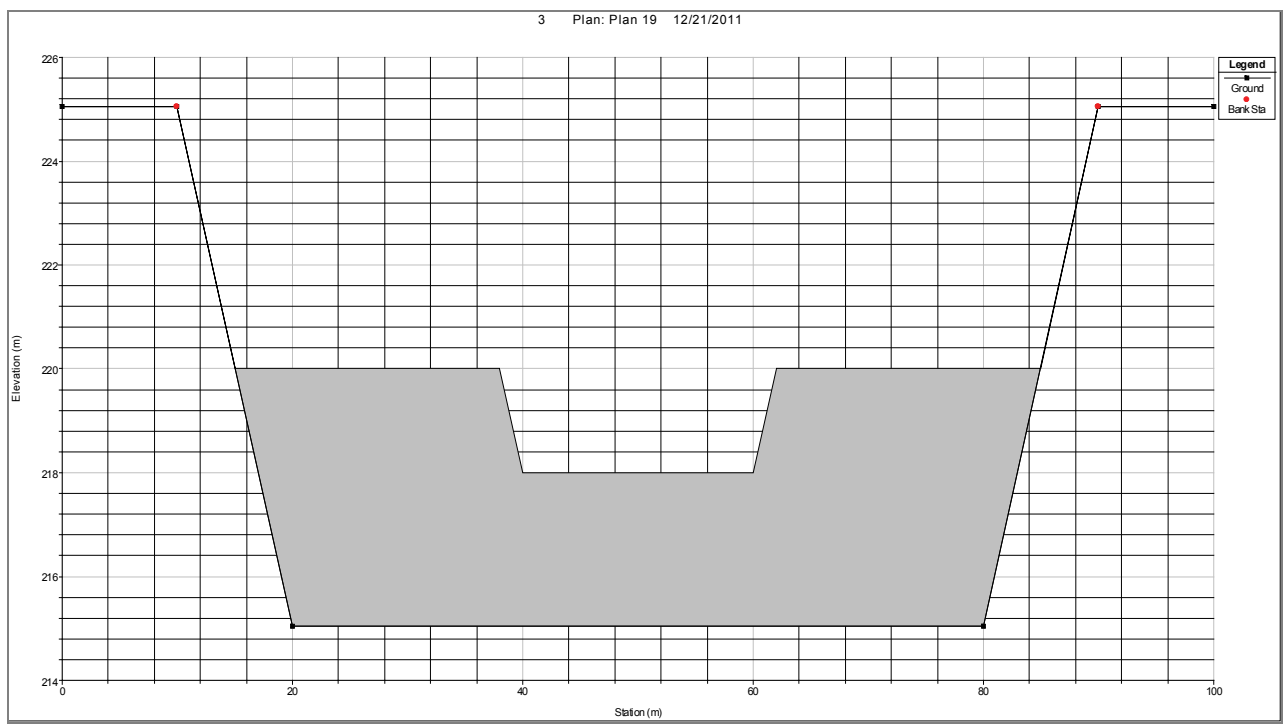

Fig. 4. Diagram of the permanent weir at $1+005 \mathrm{~km}$

\subsection{CHANNEL BED STRUCTURE}

It was assumed that the 3-m thick bed of the watercourse channel has a homogeneous structure, with the assumption that the underlying layers are non-scourable. The upper layer is composed of gravel formations.

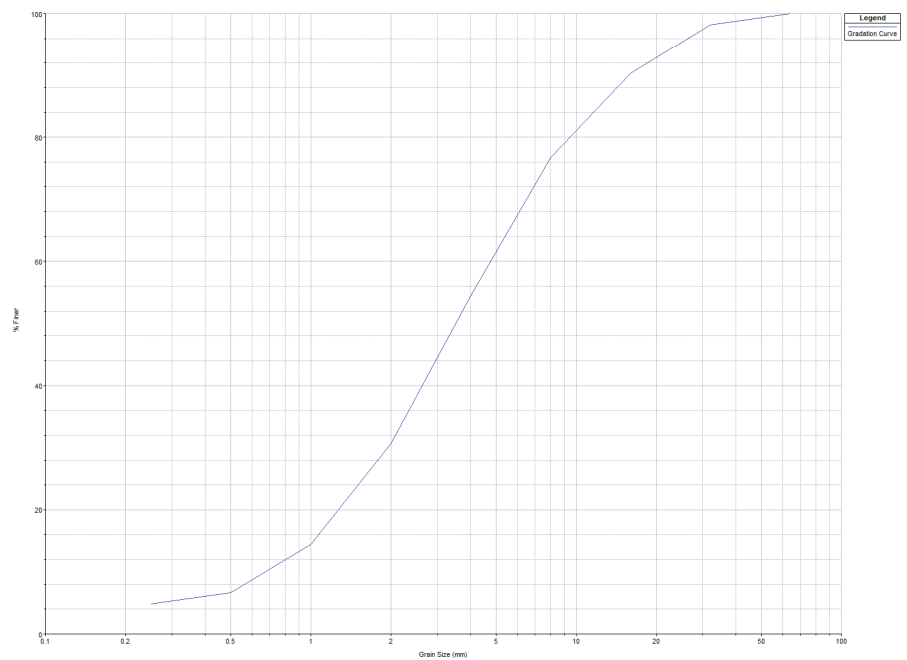

Fig. 5. Grain-size distribution curve for the watercourse bed material 
The grain-size distribution curve for the bed material is shown in Fig. 5. It was also assumed that the changeable geometry of the channel cross-section may be true for all the wetted perimeter. In the vicinity of engineering structure foundations, the bed is non-scourable.

\subsection{DISCHARGES}

The input discharge hydrograph lasted 23 months and consisted of one significant flood $\left(1900 \mathrm{~m}^{3} / \mathrm{s}\right.$ at the peak), three minor ones and one short, 70 -day long period of low stages. Moreover, over the reach between $9+500$ and $9+00 \mathrm{~km}$, the watercourse is recharged with uniformly distributed inflow of $25 \mathrm{~m}^{3} / \mathrm{s}$ and point inflows at $9+00 \mathrm{~km}$ (inflow of $55 \mathrm{~m}^{3} / \mathrm{s}$ ) and at $0+600 \mathrm{~km}\left(200 \mathrm{~m}^{3} / \mathrm{s}\right.$ inflow). The uniformly distributed inflow may correspond to a natural situation of seepage through the levee of a neighbouring reservoir with changeable water level dependent on the stage in the main watercourse discussed. The point inflows correspond to recharge by two tributaries of the main watercourse.

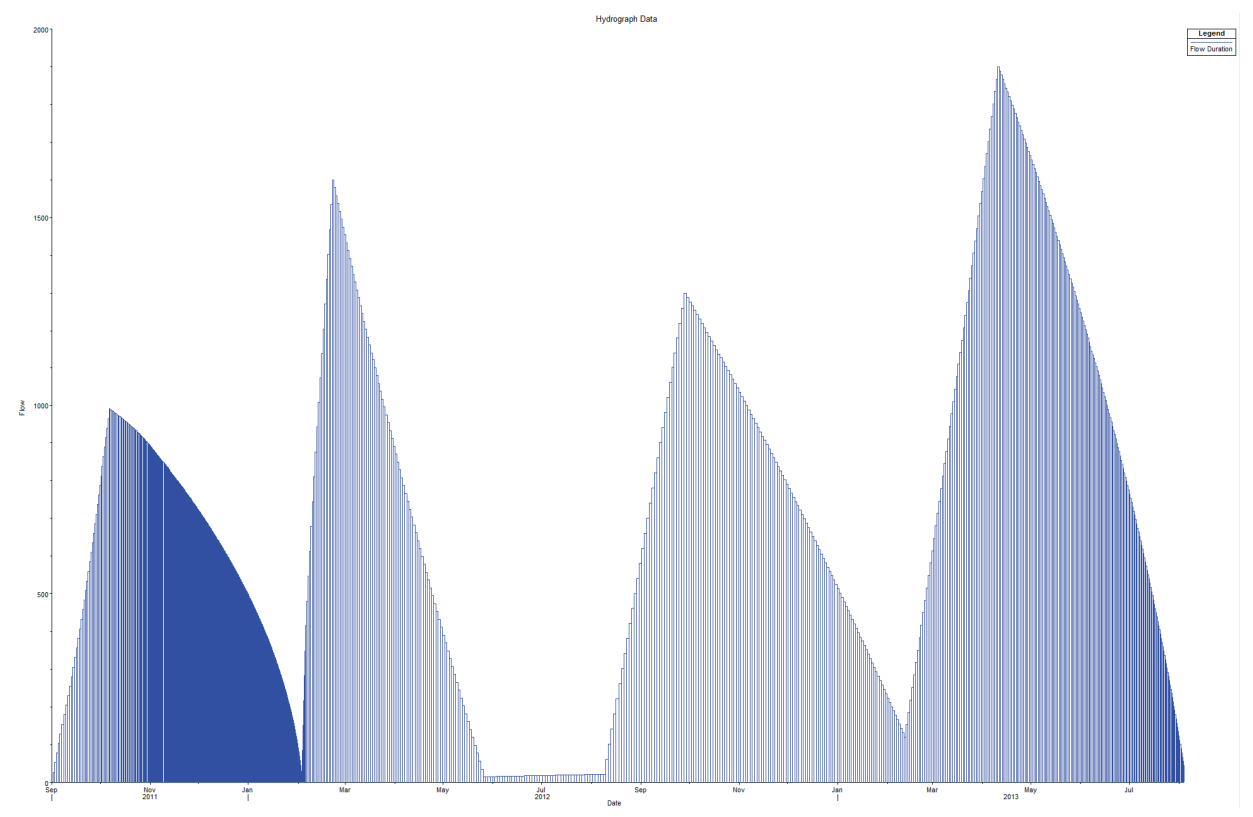

Fig. 6. Input hydrograph

In each case, inflows can be presented in the form of hydrographs. The modelled reach at $0+00 \mathrm{~km}$ is closed with a rating curve obtained from the progress of the largest flood without hysteresis. The input hydrograph is shown in Fig. 6. 


\subsection{WATER TEMPERATURES}

The values of hypothetical daily temperatures were worked out from the hydrological annual report for surface waters. The adopted model was the 1981 yearly water temperature distribution for the river Odra at Racibórz Miedonia cross-section. The temperatures ranged from 2.6 to $20.5^{\circ} \mathrm{C}$.

\subsection{METHODS}

The HEC-RAS software offers 6 functions (Ackers-White, Engelund-Hansen, Laursen, Meyer-Peter-Müller, Tofalleti, and Yang) for calculating sediment transport intensity. Two of them were chosen: Ackers-White formula, which enables calculating total bed load and suspended load discharge, and MPM function recommended for flood wave passage conditions (Kasperek and Parzonka [1]). Parameter values of sediment transport intensity for both functions are shown in Table 1.

Table 1

Parameter values of transport intensity according to Kasperek and Parzonka [1]

\begin{tabular}{|l|c|c|c|c|c|c|c|}
\hline \multicolumn{1}{|c|}{ Function } & $d$ & $s$ & $V$ & $h_{\mathrm{av}}$ & $I$ & $B$ & $T$ \\
\hline Ackers-White & $0.04-7.0$ & $1-2.7$ & $0.07-7.1$ & $0.003-0.427$ & $0.06-37$ & $0.07-1.22$ & $8-32$ \\
\hline MPM & $0.4-29.0$ & $1.25-4.0$ & $0.64-2.87$ & $0.009-1.189$ & $0.2-20$ & $0.15-2.01$ & - \\
\hline
\end{tabular}

where:

$d$ particle diameter [mm],

$s$ relative density,

$v_{\text {av }}$ mean velocity $[\mathrm{m} / \mathrm{s}]$,

$I$ water table slope [\%o],

$B$ water table width [m],

$t$ water temperature $\left[{ }^{\circ} \mathrm{C}\right]$.

A significant element of sediment transport calculation is the choice of a suitable function enabling obtaining good agreement between calculations and field measurements. This choice should be based on analysing the formula, with particular attention to the application range (Kasperek and Parzonka [1]). The results obtained by means of computer simulation do not indicate that MPM function is the best one. This is due to the fact that the model obtained exhibits numerical instability, which does not mean that it is impossible to obtain good calculation-measurement agreement while using this formula. However, such a comparison was not the authors' objective, as, beside other reasons, they did not have access to the appropriate data essential for conducting such an analysis. 


\section{SUMMARY AND CONCLUSIONS}

The solutions obtained from the simulation indicate that HEC-RAS program is a satisfactory tool for sediment transport intensity calculations. As it is a quasihydrodynamic model, preparing input data and their reliability are very important. Competent implementation of input data, especially the choice of step and calculation accuracy, based on experience and knowledge of flow modelling and sediment transport, enables quite a good reproduction of the phenomena, comparable with that obtained from a hydrodynamic model.

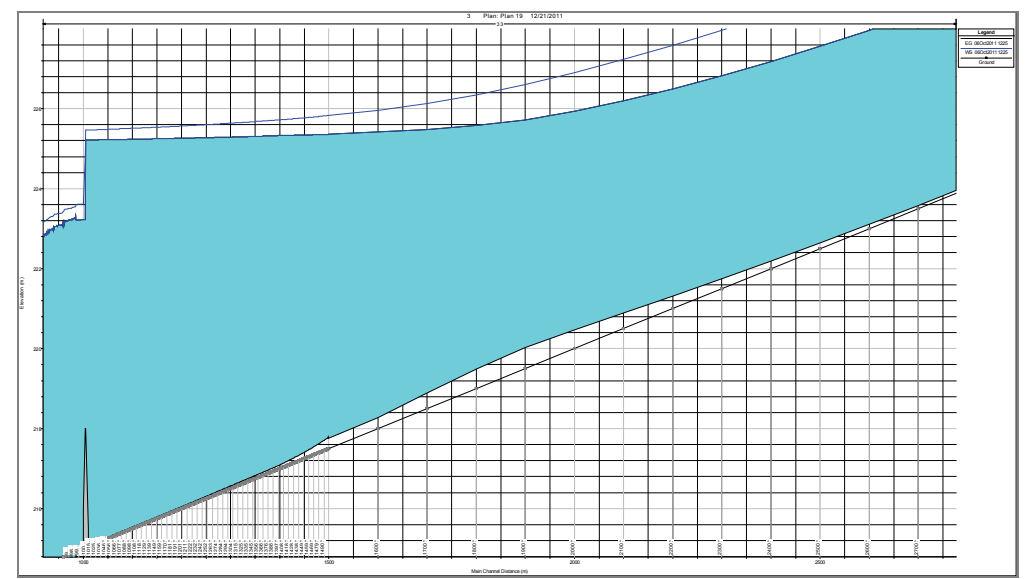

Fig. 7. October 6, 2011 - reach upstream of the weir, between $1+00$ and $2+700 \mathrm{~km}$ - sediment accumulation

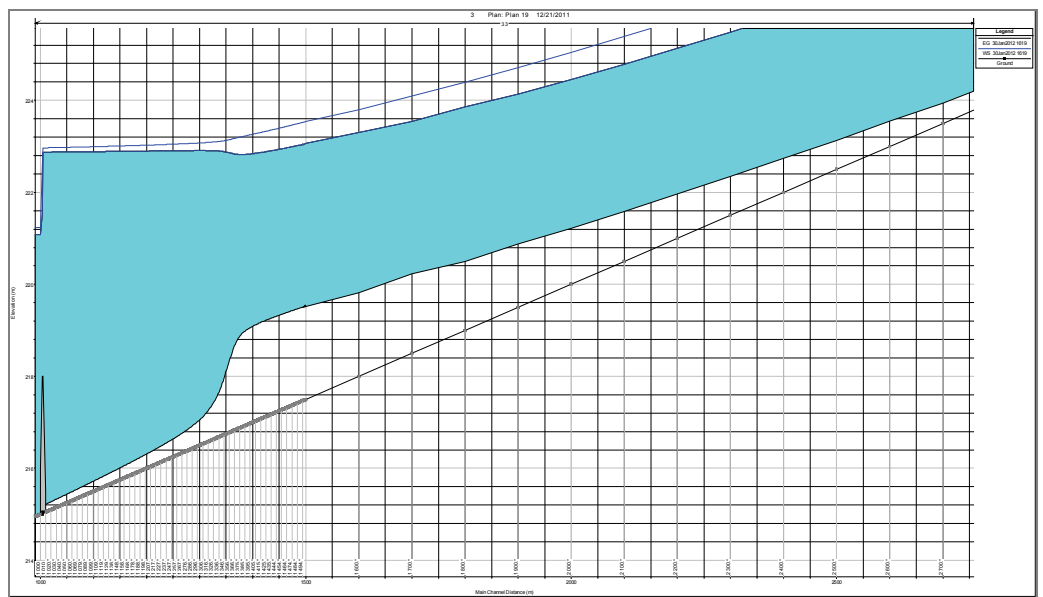

Fig. 8. January 30,2012 - reach upstream of the weir, $1+00 \mathrm{~km}$ to $2+700 \mathrm{~km}$ - sediment accumulation 


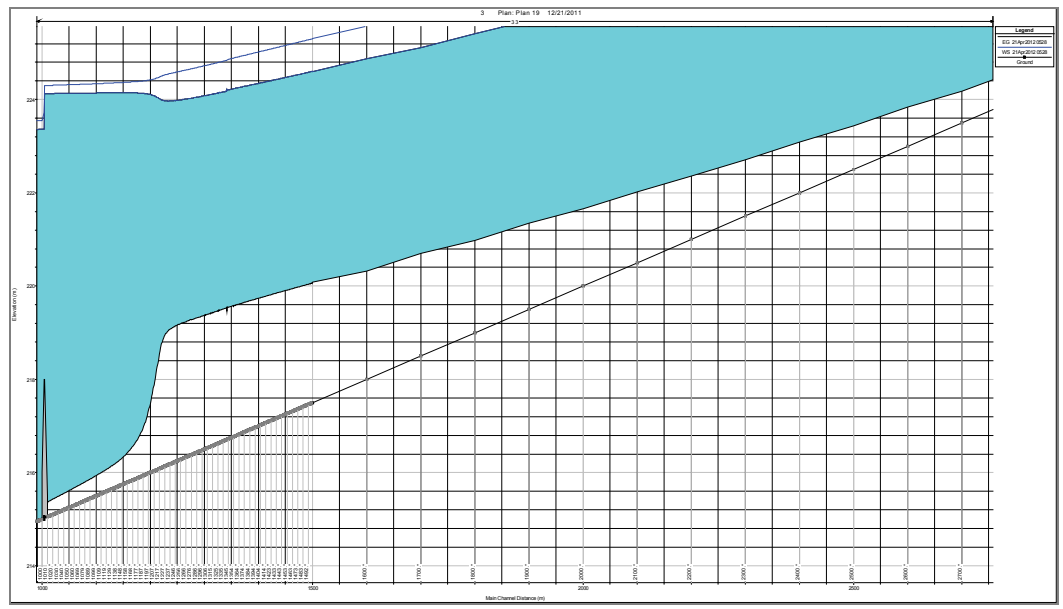

Fig. 9. April 21, 2012 - reach upstream of the weir, $1+00 \mathrm{~km}$ to $2+700 \mathrm{~km}$ - sediment accumulation

Figures 7, 8 and 9 show successive stages in channel bed evolution along the reach between $1+00$ and $2+700 \mathrm{~km}$, upstream of the permanent weir. As expected, like in real-life conditions, the channel bed along this reach was significantly raised as a result of the accumulation of sediment which had been washed away from an upper station, upstream of the cross-section at $8+00 \mathrm{~km}$. This is the result of one of the scenarios that assumed channel erosion at the initial reach and sediment accumulation in favourable places (impoundment and decrease in flow velocity).

At this stage of model calibration, it is difficult to determine the quantity of the transported material, as real-life conditions could not be referred to due to the lack of measurements. However, a family of numerically stable solutions was obtained, which will enable future verification of the quality of model's correspondence to real-life conditions.

\section{REFERENCES}

[1] KASPEREK R., PARzOnKa Wł., Transport rumowiska i pomiary obrukowania dna koryta górnej Odry w rejonie granicznych meandrów, Przegląd Naukowy IiKŚ, Rocznik XVII, 2008, Zeszyt 3 (41), 12-19.

[2] HEC-RAS Hydraulic Reference Manual, http://www.hec.usace.army.mil/software/hecras/documents/hydref/. As of 20 December 2011.

[3] HEC-RAS User's Manual, http://www.hec.usace.army.mil/software/hecras/documents/userman/index.html. As of 20 December 2011.

[4] Rocznik hydrologiczny wód powierzchniowych Odra, IMGW WkiŁ, 1981.

[5] Simon M., Doyle M., Kondolf F.D., Shields Jr., Rhoads B., McPhillips M., 2007, Critical evaluation of how the rosgen classification and associated "natural channel design" methods fail to integrate and quantify fluvial processes and channel response, Journal of the American Water Resources Association, Vol. 43, http://ddr.nal.usda.gov/bitstream/10113/7764/1/IND43976479.pdf. As of 20 December 2011. 
[6] YANG C.T., 2008, GSTARS Computer Models and Sedimentation Control in Surface Water Systems, The 3rd International Conference on Water Resources and Arid Environments (2008) and the 1st Arab Water Forum. http://faculty.ksu.edu.sa/72005/Papers\%20of\%20Interest $\% 20$ Water/GSTARS\% 20Computer $\% 20$ Models $\% 20$ and $\% 20$ Sedimentation $\% 20$ Control $\% 20$ in $\% 20$ Surface $\% 20$ Water.pd. As of 20 December 2011.

[7] ZENGA W., BECKB M.B., STAND, a dynamic model for sediment transport and water quality, Journal of Hydrology, 277, Elsevier, 2003, 125-133. 